UDK: 821.134.2.09-1 Алберти P.

$81 ' 255.4$

DOI: https://doi.org/10.18485/legado_hispanico.2020.ch5

\author{
Жељко Донић ${ }^{1}$ \\ Универзитет у Београду \\ Србија
}

\title{
ПОСРЕДНИЦИ И РЕЦЕПЦИЈА: ПРЕВОД И КРИТИКА ПЕСНИЧКОГ ДЕЛА РАФАЕЛА АЛБЕРТИЈА У ЈУГОСЛОВЕНСКОЈ КУЛТУРНОЈ СРЕДИНИ
}

\begin{abstract}
Резиме
У раду се изучавају различити елементи рецепције поетског дела шпанског песника Рафаела Албертија у југословенској културној средини, с посебним освртом на улогу и значај посредника (преводилаца, тумача, критичара) између песника и читалачке публике на српскохрватском језику. Полазећи од Јаусове теорије рецепције те теоријских специфичности рецепције књижевности у страној средини, књижевни превод је сагледан као нужан услов за успостављање културних и књижевних веза Албертијевог песништва с југословенским читаоцима, као и за заснивање критичког односа према његовом делу у домаћем научном амбитусу. Трагови деловања посредника, као образованог читаоца, који је у већини случајева први прималац дела, први тумач, а неретко, и први његов оцењивач у новој средини, посматрају се као вредни извори и полазиште за проучавање односа између изворног Албертијевог дела, превода у југословенској средини, нове читалачке публике и рецепције. На тим основама видокруг
\end{abstract}

$\overline{{ }^{1} \text { donzellco@yahoo.com }}$ 
очекивања домаћег образованог читаоца спрам Албертијевог песничког дела могуће је делимично реконструисати на основу анализе перспективе посредника који су га с тим делом упознали.

Кључне речи: рецепција, књижевни превод, посредници, поезија, Рафаел Алберти.

\section{Увод}

Крајем седамдесетих година XX века шпански песник Рафаел Алберти (Rafael Alberti, 1902-1999), један од најпознатијих припадника тзв. „Генерације 27“ био је на врхунцу светске славе. С полазиштем у традицији, најпре фолклору и шпанским класицима, гонгоризму, преко различитих књижевних опита авангардних покрета, па све до пуног надреализма и ангажоване књижевности, плодан Албертијев израз сазревао је непредвидиво, прилагођавајући се променама на историјској, друштвеној и личној разини, те према песниковим идеолошким и филозофским назорима. Борбени марксист и револуционар од тридесетих година XX века, постао је током Шпанског грађанског рата песнички глас левице против франкистичког насиља, што га је на крају сукоба, 1939. године, приморало да, као уосталом и највећи део напредних шпанских интелектуалаца и уметника, напусти земљу и емигрира у Мексико. Франковом смрћу и успостављањем демократије у Шпанији, након готово четири деценије изгнанства, песник се 1977. вратио у домовину. По повратку, одмах наставља политичку борбу - узима учешће на првим слободним изборима, 1978. године, и као кандидат комунистичке партије бива изабран за посланика у шпанском Кортесу.

Будући ангажован песник левице, антифашиста и комуниста, Алберти је уживао неподељене симпатије наших читалаца, критичара и песника, крунисане 1978. године признањем „Златни венац Струге“, једном од најпрестижнијих југословенских песничких награда, поводом чије доделе је исте године посетио СФР Југославију. На књижевне и културне везе с југословенском средином, посебно интензивиране током послератних деценија XX столећа, указује и са̂м Алберти, чије импресије ${ }^{2}$ сведоче о

\footnotetext{
2 У кратком уводном тексту насловљеном „Та чудесна херојска земља“, написаном у Мадриду лета 1980. године за потребе издања Јелићевог избора (1981), песник
} 
необичној популарности његове, али и уопштено шпанске поезије у Југославији:

Током година мог дугог избјеглиштва, живећи у разним земљама и тако далеко од домовине, био сам упознат, превасходно преко књиге, да су шпански пјесници Антонио Маћадо, Федерико Гарсија Лорка, па и ја са̂м, били веома познати и читани у Југославији, чак можда и више него у самој Шпанији. У она франкистичка времена наша имена су у Шпанији била забрањена (Алберти 1981: 7).

\section{Превод и рецепција: теоријски оквири за проучавање рецепције књижевног дела у страној средини}

Полазећи од становишта већине компаратиста да су „преводна и изворна књижевност две неодвојиве струје једног тока“ Јован Јанићијевић (1977: 187) подсећа да их треба изучавати у њиховој „сложеној међузависности и неразлучивости“, што нужно подразумева успостављање теоријског односа међу овим појавама, нарочито ако се претпоставља да изучавање преводне књижевности представља само део проучавања националне књижевности, у оквиру израде историје националне књижевности у свој њеној сложености (Јанићијевић 1977: 186).

Премда се мора признати оправданост замерки које су Јаусовој теорији рецепције ${ }^{3}$ упућиване по питању „објективне

изражава задовољство што ће у Југославији његове песме објавити баш црногорски издавач „Побједа“. О Црногорцима, Црној Гори и „њеној древној престоници Цетињу“, говори с епским надахнућем и дивљењем: „Још од својих школских дана, када сам чуо прве приче о Црној Гори, почео сам да гајим симпатије за тај комад чудесне земље, тврде и херојске, која је својом великом пасијом према поезији и слободи натјерала свијет да је воли и поштује [...] Касније, преко мојих црногорских пријатеља које данас имам, сазнао сам да су Црногорци свом националном пјеснику Његошу подигли велики споменик, можда најимпресивнији у цјелој Југославији, што ми је још више помогло да схватим смионост овог народа, тако маленог по броју и тако великог по својој вјековној борби за слободу“ (Алберти 1981: 8).

3 Јаус (1978: 58) је у студији „Књижевна историја као изазов науци о књижевности“ потцртао захтев нове књижевне историје да се традиционална естетика производње и приказивања заснује на теорији рецепције и деловања, чиме би се срушиле предрасуде историјског објективизма. Историчност књижевности отуд „не почива на post festum успостављеној повезаности 'књижевних чињеница', већ на претходном, преко читаоца оствареном, искуству књижевног дела. Овај дијалошки однос је за историју књижевности и примарна датост. Јер, историчар књижевности и сам мора најпре постати читалац пре него што узмогне да једно 
истраживости“ видокруга очекивања и рецепције књижевности, нарочито оне настале у прошлости ${ }^{4}$, одређене релације између дела, читалачке публике и рецепције извесно је могуће барем делимично реконструисати, како на основу постојећих извора (често малобројних), тако и на основу мишљења образованих или компетентних 5 читалаца, за чијим ауторитетом се тзв „ћутљива већина“ (Маркјевич) обично поводи, а које замењује искуство настало посредством лектире и пред-разумевањем света живота (Буњак 1998: 6). Управо захваљујући образованом читаоцу може се наслутити „идеална пројекција“ једног дела и његове рецепције, односно многоврсност међуодноса књижевног дела и публике, те је стога у историјској пројекцији књижевне рецепције, објашњава у раду $O$ питању историје рецепције стране књижевности Петар Буњак (1998: 8), образовани читалац „извор незаменљивих сазнања“ а самим тим, после самог књижевног дела „друго основно истраживачко полазиште“.

Писци, посредници и примаоци дела у области упоредне књижевности начелно су стављени у равноправан положај али је приликом проучавања књижевних веза питању посредника несумњиво придавано најмање значаја, док је њихова улога неретко занемаривана или превиђана (Јанићијевић 1977: 190). Нешто више пажње посветили су им теоретичари упоредне књижевности у својим методолошким разматрањима, наглашавајући, попут француског компаратисте Пола Ван Тигема (Paul Von Tieghem) да међу разноврсним модусима размене књижевних утицаја између појединих народа и култура веома значајно место припада посредницима, који олакшају ширење и прихватање страних

дело разуме и класификује: другим речима, да сопствени суд утемељи са свешћу о месту сувременог му становишта у историјском низу чинилаца."

${ }^{4}$ Теорија рецепције у тријади аутор-дело-прималац првенство даје односу дела и примаоца. Твртко Куленовић (1988: 227) указује на могуће релације дела и читаоца, где се између прошлости и садашњости развија дијалошки однос: савремено дело / савремени читалац; прошло дело / прошли читалац; прошло дело / савремени читалац; прошли читалац / савремено дело; савремено дело / прошли читалац; савремени читалац / прошло дело.

${ }^{5}$ Већ је Волфганг Изер, развијајући своју теорију деловања према улози коју врше у односу на текст диференцирао више различитих типова читалаца (савремени читалац, затим информисани читалац и намеравани читалац, према одговарајућим профилисаним типовима читаоца, итд); образованом или компетентном читаоцу одговарао би идеални читалац, који у суштини представља фикцију односно идеал култивисаног читаоца који би оличавао тип критичара (Вучковић 2008: 132). 
књижевних дела, идеја и облика у корпус националне књижевности. Ван Тигем разликује неколико врста посредника, међу којима појединце, друштвене средине или групе, критику у периодичним издавањима и монографским публикацијама, те напосе преводе и преводиоце (арид Јанићијевић 1977: 190-191).

Превод је сам по себи чињеница која сведочи о рецепцији одређеног књижевног дела у страној средини (Водичка) као о конкретизацији, будући да преводиоца средина одређује као појединца који је истовремено први читалац дела страног писца, његов први тумач а врло често и први критичар. У страну средину писац ретко улази директно, већ се читаоцима обраћа путем посредника, чију личност обликују и неки важни елементи средине (самобитни књижевни процес, традиција, публика и њен видокруг очекивања, итд) предодређујући у великој мери стереотипе књижевне рецепције (Буњак 1998: 20-21).

Према Ван Тигему превођење је у већини случајева нужно средство ширења стране књижевности, а проучавање превода представља неопходан услов и за настанак радова из области компаратистике. То значи да је најважнији задатак на овом научном пољу проучавање превода, поређење с оригиналом, међусобно поређење различитих превода - како са становишта верности и потпуности, тако и спрам особености преводиочевог поступка затим, анализа друштвене и књижевне биографије преводиоца, те напослетку, изучавање пропратних текстова, предговора и/или поговора који могу да пруже драгоцене податке о склоностима и ставовима преводиоца, читалачкој публици или, уопште, о датој средини (Јанићијевић 1977: 191).

\footnotetext{
${ }^{6}$ Појам средина, који ћемо и у овој раду користити у сличном одређењу, Буњак (1998: 15) дефинише као „временски и просторно ограничен, културно и историјски дефинисан ареал (нација, друштвена група) који уз помоћ осећања припадности апсорбује пре свега читаоца. Са становишта синхроније, у једној тачки временске осе, средина је нација (или ужа социолошка категорија) као колектив са целокупном својом политичком и културном прошлошћу, са свешћу о тој прошлости, са својом материјалном и духовном културом и њеним одговарајућим установама. [...] Тако схваћена средина је, дакле, категорија надређена читаоцу, шира је и од публике, али и од саме националне књижевности. Она је заправо скуп свих дистинктивних обележја једне националне, територијалне или друштвене заједнице која активно утичу на дефинисање у целини.“ (Буњак 1998: 15).
} 


\section{Иницијално интересовање за песништво Рафаела Албертија у југословенској средини}

Прве песме Рафаела Албертија у Југославији, појављују се тридесетих година XX века, прво у књижевној периодици, где налазимо да је Хајим Алкалај 1936. године, у Прегледу превео Албертијеву песму „Позив харфи“. У првој југословенској антологији шпанског песништва (1954) Алберти је представљен скромно, са свега пет песама, из збирке о анђелима, а састављач и преводилац тог избора, Миодраг Гардић у белешци о њему кратко пише да се „борио против Франка“, да је сада политички емигрант у Америци, те, да му је поезија „оригинална, прожета изненађујућим мотивима и сликама" (Гардић 1954: 75). Никола Милићевић (Антологија новије шпањолске поезије, 1959) крајем шесте деценије XX века за Албертија каже да је један од највећих и најинтересантнијих шпанских песника, „[к]омплексан [...], богат и разнолик, као ниједан од његових савременика", доноси у преводу па српскохрватски петнаест композиција из његових до тада објављених збирки (Милићевић 1959: 14). Према нашим сазнањима први је од српских преводилаца у периодици поезију Рафаела Албертија шездесетих година почео преводити Душко Вртунски, објавивши у Летопису Матице српске, 1963. године кратку љубавну песму „Зора која именује" (El Alba Denominadora). Можда не случајно, те 1963. године, већ прослављени шпански песник у егзилу враћа се са путовања по земљама Латинске Америке у Европу, и настањује се у Риму. Исте године је и у Кошутићевој Шпанској лирици преведено десет његових песама. Тај скромни избор уједно успоставља модел за превођење различитих етапа његовог традиционалистичког дела опуса у еквивалентним метричким формама. Владета Р. Кошутић је (1963: 56-57) у предговору разноврсност Албертијеве поетике илустровао карактеришући овог песника као „троструког носталгичара (за завичајним рајем, за изгубљеним небом и Шпанијом) и троструког

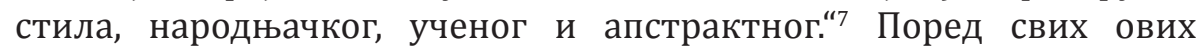
спорадичних похвала и антиципације у општим приказима поезије, интересовање за Рафаела Албертија у нашој средини сазрева тек крајем осме деценије XX века, захваљујући понајвише

\footnotetext{
7 Рафаел Алберти представљен је највећим делом песмама из збирки Морнар на копну и О анђелима. Кошутић (1963: 283) истиче да је „као пример савременог 'гонгоризма' препеван само први део Албертијеве „Сирене“, а из поеме „Тиртеј“, („Метак и два метра земље...”) изабран је низ најлепших двостиха“.
} 
ванлитерарним, историјским факторима који су тог песника у нашој средини учинили много познатијим и признатијим, омогућивши му да се представи у форми књиге, што је уједно и први и нужан услов за рецепцију у ширем читалаштву.

\section{Јордан Јелић}

У померању видокруга очекивања домаће публике када је реч о Рафаелу Албертију током седамдесетих година у Југославији, најважнију улогу одиграо је Јордан Јелић. По струци компаратиста и социоантрополог, а по вокацији есејиста, преводилаци песник, Јордан Јелић (1942-2012) био је један од најеминентнијих југословенских културних посленика који се бавио хиспанским и латиноамеричким темама током друге половине XX века. Поред поезије Рафаела Албертија преводио је још и поезију Никанора Паре, Октавија Паса, Пабла Неруде, Сесара Ваљеха, Федерика Гарсије Лорке итд. Аутор је и више књижевно-теоријских огледа и антрополошких студија. Он је прво 1973. године за крушевачку „Багдалу“ превео Албертијеву песмарицу Драгана (La amante), што је прва Албертијева интегрална песничка збирка на српскохрватском језику. Издањем тог превода долази до иницијалног пробоја Албертијеве поезије у нашој средини. Јелић је Албертија на крају књижице представио кратком белешком у којој наглашава да је велики песник „топлином свог шпанског југа и вјечног путника створио засебни поетски свијет: комплетан, разнолик, чудан, чудесан, необичан...” јер је сваком својом књигом „негирао“ пређашњу „афирмирајући истовремено силну енергију, рјечитост, неисцрпност у спонтаном изричају широког спектра варијација“ (Јелић 1973: 34, 37). Јелић наглашава да Албертијеве раније збирке (Морнар на копну, Драгана, Зора шебоја, Пјесма и креч) „изразито кореспондирају кроз лирске интонације непопуларизма [sic] и модалитета гонгоризма, творећи мале композиције живих тонова..., док за збирку $O$ анђелима каже да је представљала „прворазредно изненађење“ будући у исти мах „почетак и врхунац надреалистичке шпанске поезије“ (Јелић 1973: 35).

Пратећи трагове Јелићевог деловања наишли смо потом на превод у сарајевском часопису за књижевност и културу Живот, где је 1975. године објавио и прву интегралну верзију превода Албертијеве прослављене збирке Морнар на копну (1925) о чему у краткој белешци о писцу, пише: 
Књига „Морнар на копну“ коју први пут комплетну представљамо нашој јавности, у ствари је збирка носталгичних пјесама, елегија, човјека рођена поред мора. Море и све што је везано уз њега: солане, лађе, весла, љубави, снажно су присутни под топлим андалужанским сунцем. Младеначки занос Р. Албертија даје им склад и љепоту, коју у себи носи само прави пјесник (Јелић 1975: 50).

Један део песама из поменутих збирки, уз још неколико нових, Јелић је 1978. публиковао и у књижевном часопису Поље. ${ }^{8}$

Најзначајнији допринос Јелића рецепцији Рафаела Албертија у нашој средини представља антологија Морнар на копну и друге песме, коју је 1981. године саставио и превео за „Побједу“ из Титограда. Јелић је ово јамачно учинио и због тога што су његови преводи из књижевних часописа које смо горе навели, остали непознати широј читалачкој публици. Јелић (1981: 130) вели да је у овом издању настојао више простора дати композицијама о мору и „анђелима“,

\begin{abstract}
${ }^{8}$ Реч је о песмама „Мадригал о снегуљици „Сирена дјевица“, „Једном капетану“, „Федерику Гарсији Лорки“, „Рози Алеберти која је сетна свирала на харфи“, „Полетјети!“, „Успаванка мртвоме дечаку“, „Срна моја“, „Од два, до три“, „Земљотрес“, „Елегија“, „Драгана“, „Госпођици Х, сахрањеној у западном ветру“, „Добри анђео“, „Телеграм“, „Галоп“, „У петој сам регименти!“, Јордан Јелић 1978, у: Поље, год. 24, бр.
\end{abstract} 230, 1978: 20-21.

9 Морнар на копну („Једном капетану“, „Полетјети!“, „Земљопис“, „Елегија“, „Море, сиње море“, „Уздах за морем“, „Волио бих да имам шкрге“, „Подморксо извикавање“, „Тагори“, „С пучине“, „Говорио сам ти заставицама“, „Увијек кад сањам плаже“, „Брод угљенар“, „Исциједите ме“, „Сан“, „Застори...”, „Мали од палубе“, „Другови моји“, „Сјети ме се на пучини“, „Црно сунце“, „Сиреница“, „Ко ће јахати коња“, „Ако сам рођен за сељака“, „Ако ми глас на копну заћути“, „Ларедо“, „Заборављени морнар“, „Кариби“, „Живе воде“, „Осамнаеста пјесма“, „Срна моја“, „Блиједи-Сњежни-Мјесец“, „Роси Алберти која је сјетна свирала на харфи“, „Елегија“, „Врт Ужитка“, „Од два до три“, „Драматични мадригал о ужареној-и-хладној“, „Кад би се Гарсиласо вратио“); О Анђелима („Непознати анђео“, „Добри анђео“, „Ратнички анђели“, „Анђео бројева“, „Пјесма о анђелу без среће“, „Разувјерени анђео“, „Лажљиви анђео“, „Позив на зрак“, „Добри анђео“, „Истински анђео“, „Похлепи анђео“); Пјесма и Креч („Искра“, „Непознатој Госпођици, сахрањеној у западноме вјетру“); Сликарству („Црвено“, „Жуто“, „Зелено“, „Црно“, „Бијело“); Био сам будала а оно што сам видео претворило ме је у две будале („Чарлијев тужни састанак“, „Бастер Китон тражи своју заручницу која је једна права крава“); Између каранфила и мача („Превари се голубица“). Песме из других збирки и часописа: („Урани, љубљена моја“, „Испод црне тополе“, „Кастиљани“, „Пењаранда на Дуеру“, „Лерма“, „Јуриш на ријеку“, „Не знам сада...”, „Пијевци већ пјевају“, „Зелени јежеви морски“, „Улазак у Мадрид“, „Мадригал о изгубљеном чешљу“, „По читавој Шпанији...”, „Увијек нека козица има“, „Смрт“, „Потребно је бити слијеп“, „У петој сам регименти!“, „Галоп“, „Коњ је чаршаве молио“, „Пета пјесма“, „Тридесетшеста пјесма“, „Балада о бициклу с крилима“, „Герилац“, „Просјак“. 
према његовом мишљењу „централним темама“ Албертијеве поезије, иако те песме спадају у његове ране радове. Јелић је свестан важности овог превода за рецепцију шпанске књижевности на нашим просторима, изражавајући на крају „Биљешке о писцу“ наду да ће он бар делимично надомести празнину „која одиста постоји у познавању велике шпанске књижевности у нас“ (Јелић 1981: 130). У потрази за исправним преношењем поруке и смисла са шпанског на српски језик Јелић је, како видимо, могао рачунати и на помоћ хиспаниста, што објашњава релативно мали број материјалних грешака ${ }^{10}$ :

С овом поезијом другујемо више година, објавили смо бројне преводе у многим часописима и листовима на српскохрватском подручју. Такођер, напомињемо да је немогуће, не само због ограничености простора, већ прије свега због нарави преводилачког посла, објаснити све оне жеље и стрепње да преводи буду што је могуће бољи. Савршен превод не постоји. Преводилац се осјећа задовољним, ако успије пренијети поруке пјесме и изразити њен смисао. Свакако да дугујемо захвалност пријатељима, професорима шпанског језика, с којима смо о неким пјесмама дискутовали и од њих добили корисне сугестије (Јелић 1981: 130).

Као и преводом Драгане, и овим препевом Јелић настоји да опонаша Албертијеву ритмику, пре него метричке обрасце. Он вешто влада кратким асонованим стиховима и лако изналази звучне и спонтане сликове, по распореду који не следи увек изворну схему. Складна композиција шестераца (Море. Сuње море. / Море. Само, море), седмераца и осмераца (урани, љубљена моја... / по балустрадама) ритмичко померање усека, умешно изведене алтерације дугог и кратког стиха, Јелићев препев чине звонким и мелодичним.

Спрам преношења метричких форми Јелић се поставља двојако, од случаја до случаја. Док краће шпанске стихове народног карактера и verso fluctuante, често преноси адекватним метрима, било исте дужине, било нашим „народним“ еквивалентом, класичне и сталне облике преводи слободније, тежећи да ритам и тоналност песме ухвати у „белом стиху“.

\footnotetext{
10 Премда има упитних места, многозначност песничкога језика неретко не искључује ни понуђена решења, попут синтагме из наслова збирке Цалу цанто, коју је Јелић дословно превео као Пјесма и креч. Изгледније је ипак да је овај устаљени израз који може значити да је шта (као) „опеком зазидано“, Кринка ВидаковићПетров превела исправније и песнички успелије, као „Стамен камен“.
} 
У песми „Заборављени морнар“ (Marinero olvidado) Јелић складно компонује петерце и јампске седмерце (Страни бродови, кћери, / страни бродови. / Страни бродови / усидрени у лущи); у песми „Кариби“, за коју бисмо рекли да спада у успелије, и у којој се складно смењују три дужа (осмерац или деветерац) и два краћа стиха (четверац-шестерац) у маниру шпанске „преломљене стопе“ рима је спорадична и игра улогу тек помоћног сигнала Албертијевом ритмичном набрајању: Кариби, пламен што плаче. / Кариби, qиепа што пати. / Кариби, луна што излази, / смрт што слуша, / кожа што се свија, (Алберти 1981: 38).

С друге стране, сонет „Једном капетану“ (A un capitán de navío) препеван је слободним стиховима повезаним асонантском римом, прво у парним стиховима, а онда, у паровима асонованих дистиха, док у сонету „Роси Алберти која је сјетна свирала на харфи“ (A Rosa de Alberti, que tocaba, pensativa, el arpa) слик нестаје готово у потпуности, укључујући и асонанцу. Оваква схема римовања Албертијев сонет у првом случају приближава традиционалнијој асонантској копли, доку другом случају он постаје песма разбарушеног авангардног слободног и неримованог стиха (сем неколико можда и случајних сазвучја); и свакако губи од виртуозности и строгоће старинске форме, у дугом и мајсторски компонованом Албертијевом везаном стиху.

Преводилац је сигурније осетио тоналност Албертијевих „анђела“, како видимо у песми „Истински анђео (El Ángel Ángel),
y un apellido el viento
y las nubes un cuerpo
y un alma el fuego.
La tierra, nada.
Ese reino movible, colgado de las águilas, no la conoce.

Y el mar fue y le dio un nombre

Nunca escribió su sombra la figura de un hombre (Алберти 1972: 57).

коју наводимо као пример, упркос различитом метру и изостанку нагомилане асонанце из првог катрена у преводу, уз сличан свечан „пророчки“ тон: 
Би море и име му даде, и вјетар презиме и облаци тијело и ватра душу.

Земља ништа.

Ово покретно краљевство, што су орлови објесили, не познаје земљу.

Сјена његова никад не оцрта

фигуру човјека. (Алберти 1981: 79).

Наводили смо даје доследност у преношењу смисла програмски преводиочев став, од кога заиста ретко одступа. Занемарљива су такође померања на микростилистичкој равни. Јелићев стил се, мање или више успешно, мења и прилагођава сменама стилова Албертијевих поетских етапа.

\section{Кринка Видаковић-Петров}

Након што је 1980. у Летопису Матище српске објавила превод Албертијевих „Десет песама",11 из збирке Рим, опасност за пешаке, Кринка Видаковић-Петров ${ }^{12}$ 1986. године преводи Изабране песме, најрепрезентативнији избор из целокупног дела овог познатог шпанског песника на српскохрватском језику. За књигу у издању Београдског издавачко-графичког завода Видаковић-Петров је написала и уводни стручни текст, обимне коментаре, као и детаљну (биографску) хронологију. Адекватним преводом чак 113 песама из

\footnotetext{
${ }^{11}$ Из збирке Roma, peligro para caminantes, „Пешаци чувајте се Рима“, „Забрањено мокрити“, „Кампо де Фиори“, „Песнички живот“„,Базилика С. Петра“, „Господе, буди милосрдан“ (264); „Улазим у цркве твоје“, „Артритис II“ „Мост дојки“ „***[Борба са мачкама у Риму...]“. Све ове песме са мањим изменама укључене су и у антологију Изабране песме (1986). Вид. Библиографија: Алберти, Рафаел.

${ }^{12}$ Кринка Видаковић-Петров основне студије завршила је на Одсеку за енглески језик и књижевност Филолошког факултета у Београду (1969), где је на Одсеку за светску књижевност и магистрала, 1972. године. Докторат на тему Култура шпанских Јевреја на југословенском подручју одбранила је на Филозофском факултету Загребачког свеучилишта 1982. године. У Институту за књижевност и уметност ВидаковићПетров ради од 1970. године, истражујући највише у областима хиспанистике, јудаистике, фолклористике, компаратистике и књижевног превођења.

http://www.ikum.org.rs/people.php?id=1
} 
22 збирке, антологија српским и југословенским читаоцима отвара могућност да се упознају са свим дотадашњим етапама Албертијевог плодног стваралаштва. ${ }^{13}$

Представљајући несвакидашње завојиту путању утицаја и поетика Албертијевог песничког дела, Видаковић-Петров (1986б: 7) као најпоузданији примењује хронолошки принцип, истичући да ће читалац, када опус овог песника сагледа у временском низу - што омогућавају избор и редослед композиција у антологији - „запазити разноврсност песама и уочити одсуство праве линије развоја“: „Док се поједини песници, више или мање доследно, уз већа или незнатнија

\begin{abstract}
${ }_{13}^{13}$ Морнар на копну („Милог ми јеленка“, „Земљопис“, „Гусар“, „Са пучине“, „Елегија за Хелејеву комету“, „Мадригал за белу-снежу“, „Не би лепша лађа пловила“, „Умре ли мој глас“, „Капетан брода“); Драга („У пролазу“, „Ла Ора“, „Из Каникосе де ла Сиере“, „Лерма“, „Христос из Бургоса“, „Христос из Бургоса“, „Побожна песма“, „Од Бургоса према Виљаркају“); Зора шебоја („Уочи бекства у Мисир“, „Тамничарко, откључај браве“, „Под маслином“, „Иснахарска кула“); Стамен камен („Анђели зидари“, „Мадригал за трамвајску карту“, „Венера у лифту“, „Мој погреб“, „Искра“, „Телеграм“, „Miss X, сахрањеној у западноме ветру“); O анђелима („Ратоборни анђели“, „Анђео бројева“, „Разочарани анђео“, „Пепелни анђео“, „Анђели журбе“, „Окрутни анђели“, „Анђео анђео“, „Угљени анђео“, „Завидљиви анђео“, „Осветнички анђели“, „Пламени пас“, „Глупи анђео“, „Успеће“, „Неми анђели“, „Добри анђели“, „Грамзиви анђео“ и „Анђели месечари“); Био сам будала а оно што сам видео претворило ме је у две будале („Шарлоов тужни састанак“, „Бастер Китон по шуми тражи своју вереницу која је права крава“, „Five o'clock tea“); Проповеди и боравишта („Збогом крви“); Неки баук кружи Европом („Неки баук кружи Европом“); Престонища славе („Ноктурно“, „Магли, моме псу“, „Интернационалним бригадама“, „Елегија за песника који није умро својом смрћу“, „Мадрид-јесен“); Између каранфила и мача („Голуб се преварио“, „Све ужасно, мрачно“, „Страх се чуо као зарђала шарка“); Плима („Сви смо веровали“, „Песме“); Сликарству („Црвена“, „Бош“, „Гоја“ и „Миро“); Песме из Пунта дел Есте („Стари вук“, „Шума је голема и пуста“); Повратак оног што је живо и далеко („Повратак једног рођендана“, „Повратак љубавни на једној тераси“, „Повратак Јехуде Халевија Кастиљанца“, „Повратак слатке слободе“, „Повратак пред шпанским обалама“); Приморје и приморци („Кадис, сан мог детињства“, „Бекство пророка Јоне у Тарисис“); Баладе и песме паране („Балада о комарцима“, „Дошао сам у самоћу“, „Да песма буде мања од зрна“, „Није ви више стало да будем нов“, „Не стидим се да певам“, „Хтео бих да певам“, „С каквом тугом“„,Балада за оног ко никад није био у Гранади“); Отворено у свако доба („Лајао бих и ја“, „Бешумна јесен ове шуме“, „у том граду јесен је тад била“, „Изгажена јесен одлази“, „Слике, река, возови, авиони“ Матадор („Матадор“, „Статуа“, „Калуђер“, „Сахрана“, „Непредвиђено“, „Тај генерал“, „Више-мање“, „Ситуација“, „Продавац“); Рим, опасност за пешаке („Рим, опасност за пешаке“, „Забрањено мокрити“, „Кампо де Фиори“, „Песнички живот“, „Сервантес је ушао у Рим“, „љубав“, „Базилика Св. Петра“, „Господе, буди милосрдан“, „Борба с мачкама у Риму“, „Мост дојки“, „Артритис (II)“); Осам Пикасових имена („Мир“); Песме из високе долине Аниене („На маслини“, „Село је опустело“, „Пукотина у камену“, „)а добро знам“); Свеске песничке свакодневнище („Свиће, чини ми се“, „Поезија је кад нећеш да се скрасиш").
\end{abstract}


одступања придржавају начела једне поетике, код других су такве привржености краткорочне и неотпорне пред изазовима другачијих и неискушаних могућности писања и књижевног деловања. Међу ове друге сврстава се и Алберти, који је превасходно био и остао песникпрактичар, на кога су више утицале околности личног живота и који се ређе укључивао у друштвене сукобе, него што се бринуо о чистоти слова песничких прогласа и о верности школама, групама и правцима“" (Видаковић-Петров 1986б: 7).

Да је Видаковић-Петров превод Албертијевих песама припремала темељно и с јасним преводилачким усмерењем, препознаје се по малом броју материјалних грешака и упитних места, занемарљивим семантичкимпомерањима теисцрпним коментарима који, ослањајући се на релевантну литературу, сваку појединачну песму тумаче и осветљавају у књижевно-историјском, теоријском или биографском контексту. Закључци изнети у „Коментарима и напоменама" у бројним случајевима били су корисни за доношење важних преводилачких одлука (избор метра, ритам, регистар) те одабир стилских средстава у макростилистичком нијансирању превода различитих етапа Албертијевог стваралаштва. Показаћемо на неким карактеристичним примерима.

У коментару песме: „Милог ми јеленка“ (из Морнар на копну) коју је Алберти написао „на народну“, инспирисан кратком анонимном композицијом из Барбијеријеве Музичке песмарице („У Авили, очи моје“, XV век),

Mi corza, buen amigo, mi corza blanca.

Los lobos la mataron al pie del agua.

Los lobos, buen amigo, que huyeron por el río.

Los lobos la mataron dentro del agua (Алберти 1972: 37).

Видаковић-Петров (1986а: 241) полази од мотива љубавног састанка на извору познатог и у шпанској и у српској усменој традицији, те наслов песме - mi corza - у прецизном преводу „моја срна“, преводи Милог ми јеленка, јер се лексема јеленак, по 
ауторкиним речима у нашој народној поезији може асоцирати са темом невине смрти вољене особе из бугарштице о Марку и Андријашу. Правилни седмерци и петерци Албертијевих дистиха (7-5 7-5 7-7 7-5) и асонантска рима у парним стиховима

Белог јелена, пријатељу добри, милог ми јеленка,

растргоше вуци

крај извора.

Вуци, пријатељу добри

који побегоше реком.

Вуци га у води

растргоше. (Алберти 1986: 29).

замењени су, по сличној схеми алтерације дугих и кратких, нашој народној традицији уобичајенијим трохејима: четверцима, шестерцима и осмерцима (5/6-6 6-4 8-8 6-4); слик је у складу са изворником те особинама наше народне лирике сведен, и ослоњен на сазвучја настала понављањима (добри, добри), асонанцом (добри, води) те подударањем клаузула (јелена/извора). Замена редоследа синтаксичких елемената у прва два стиха, избор адекватних средстава из усменог регистра и архаичних облика („милог ми“ уместо „мог“; „вуци“ уместо „вукови“) песму прикладно приближава домаћој фолклорној матрици.

Слично је и с другим песмама из збирке Морнар на копну, где Видаковић-Петров стихове преводи ослањајући се на фолклористичка и компаратистичка запажања. Правилни осмерци, у песми „Земљопис“ (Geografía física), испеваној древном формом виљансика, замењени су разноврсним стихом, у првом делу највише ритмички складним шестерцима и осмерцима, али и паровима дужих стихова, једанаестерца, са сликовима који само донекле следе изворну схему виљансика, преносећи изворне асонанце или праве чисте риме A pie de la mar morena, / solo, en un banco de arena: Тако крај мора где је вода црна / седи на клупи од пешчаних зрна или Partiendo el agua, un bajel sale del fondeadero. / Camino del astillero, / va cantando el timonel: Крстарица је сидро дигла / таласи под крмом брује, / кормиларева се песма чује, до излаза још није стигла / (Алберти 1986: 30). Асонанце је Видаковић-Петров распоређивала по нешто 
измењеном распореду, асонујући међ собом дистихе (Земљопис нико не зна ( као моја сестра; Два залива спаја ( плава јегуља канала); таквим распоред риме постиже се у нас прикладна атмосфера дечје песме, и асоцијација на Кадис и песниково детињство. Сонет „Капетану брода“ ( $A$ un capitán de navío) показује преводитељкин приступ сталним формама.

Sobre tu nave - un plinto verde de algas marinas, de moluscos, de conchas, de esmeralda estelar, capitán de los vientos y de las golondrinas, fuiste condecorado por un golpe de mar.

Por ti los litorales de frentes serpentinas desenrollan, al paso de tu arado, un cantar: - Marinero, hombre libre que los mares declinas, dinos los radiogramas de tu estrella Polar.

Buen marinero, hijo de los llantos del norte, limón del mediodía, bandera de la corte espumosa del agua, cazador de sirenas;

todos los litorales amarrados del mundo pedimos que nos lleves en el surco profundo de tu nave, a la mar, rotas nuestras cadenas (Алберти 1972: 64).

Шпански александринац Видаковић-Петров такође није настојала да опонаша (ни као симетрични четрнаестерац, ни као нашу симетричну дванаестерачку адаптацију),

Морски талас те постави за капетана брода - корита зелена од бесцветног биља, звездана смарагда, шкољки и трава заповедника ветрова и ластавичјих крила.

Стрме обале серпентинских гора по проласку твог броја песму поје:

- Поморче слободни, што оплови мора, покажи нам радиограм Северњаче твоје.

Поморче добри, што ловиш сирене носећи дворски барјак од пене, сине сузе севернице, лимуне југа; 
ти си за нас сужње обала спас, раскини нам окове, ослободи, поведи нас дубоком браздом твог бродског плуга (Алберти 1986: 37).

утемељујући ритам својих флуентних стихова уместо на силабичкој, на самерљивости понављања четирију акценатских стопа̂ и разноврсних полустихова. Видаковић- Петров у првом катрену слик замењује асонанцом, растерећујући такође њен распоред увођењем још једног пара риме. ${ }^{14}$

Издање и препев Кринке Видаковић-Петров добили су веома позитивне оцене и у критичком приказу Бошка Томашевића, на који ћемо се додатно осврнути у наставку, у одељку о критичкој рецепцији. Томашевић (1987: 966) истиче да се објављивање превода изабраних песама Рафаела Албертија на српскохрватски језик дугује Кринки Видаковић-Петров, „изузетно добро упућеном преводиоцу Албертијевог дела, којега зналачки извајан торзо сада краси БИГЗову чувену библиотеку преведене поезије 'Врхови““. Томашевић (1987: 966) оцењује да је тај „значајан превод, [...] уз Томасовићев превод Песоине поезије, Мићевићевих превода Малармеа и Валерија, Живојиновићевог превода Рилкеа, те Мркоњићевог превода Хелдерлинове поезије - један од најзначајнијих преводилачких подухвата деценије."

\section{Прилог за студије критичке рецепције песничког дела Рафаела Албертија}

За критичку рецепцију песничког дела Рафаела Албертија на српском говорном подручју може се рећи да је релативно скромна јер према нашем сазнању обухвата, сем пропратних текстова у изборима песама о којима смо писали, један критички приказ књиге те неколико критичких осврта и поетичких описа. О Албертијевом песничком делу писали су код нас највише Јордан Јелић, Кринка Видаковић-Петров, и Далибор Солдатић, највише о збиркама Морнар на копну и О анђелима. Један од првих асистената на групи за Шпански језик и књижевност Филолошког факултета Универзитета у Београду - Далибор Солдатић - 1969. године на Националном Аутономном Универзитету Мексика (Universidad Nacional Autónoma

\footnotetext{
${ }^{14}$ Полустихови се у преводу јављају се по следећем обрасцу 5+8/8+6/6+5/8+6//5+8 $/ 4+7 / 6+6 / 8+6 / 5+6 / 5+5 / 8+5 / 7+9 / 5+5$; Изворна схема риме ABAB ABAB CCD EED у преводу је постала АBAB CDCD EEF GGF.
} 
de México) одбранио је магистарску тезу под насловом La nostalgia en la Obra Poética de Rafael Alberti (Носталгија у песничком делу Рафаела Албертија). Премда никада није преведена на српски језик, та студија утицала је на критичку рецепцију песничке збирке Морнар на копну у Србији. Јордан Јелић (1981: 124) нас у предговорубелешци о писцу збирци Mornar na kopnu i druge pjesme обавештава да му је Солдатићев „изузетни рад о песништву Р. Албертија много [...] помогао у разумијевању песникова стваралаштва“, где се феномен мора као носталгије „одиста минуциозно анализира“ (Јелић 1981: 124). Солдатић проналази да је у збирци Морнар на копну, у већем делу песама из првог дела књиге, море за Албертија носталгија, „која попут сна открива симболе слободе“ односно да „[м]огућности слободе и потврде властитог бића пјесник нипошто не очекује у реалном свету, већ за њим трага у 'свијету мора', магији подморја, гдје је за њега све могуће“, као и да је далеко море Америке из збирке Плима песников „друг бола“, јер само оно може разумети песника (Јелић 1981: 124-125). Солдатић је сличне погледе изложио и у кратком тексту „Морнар на копну: Рафаел Алберти (1902-1999) у часопису Овдје $(32,388 / 390) 2001$. године, повезујући у форми некролога тематске и биографске податке о песнику.

У наставку дајемо осврт на најважније написе и критичке чланке о песничком делу Рафаела Албертија.

Књига Морнар на копну и друге пјесме Јордана Јелића (1981) поред Албертијевог кратког увода, доноси још два вредна прилога библиографске и књижевне критике:

a) Јордан Јелић укључио је у ову збирку и аутобиографску белешку однесите ме на море Борислава Лалића, новинара, дугогодишњег југословенског дописника Танјуга из Шпаније. Лалић (1981: 109-122) у тексту износи низ занимљивих и мање познатих анегдота, реминисценције о сусретима са Рафаелом Абертијем и догађајима из песниковог живота којима је сведочио током боравка у Шпанији. Из текста се да̂ закључити да је Лалић с Албертијем имао присан, пријатељски однос, а теме о којима води разговор с песником разноврсне су и актуелне. Лалићев текст обилује Албертијевим медитацијама о политици, утисцима по повратку у Мадрид након готово четири деценије изгнанства, страховима и надама пред измењеном стварношћу, носталгији за морем, његовом омиљеном темом и најчешћим мотивом, затим о политичким активностима у оквиру комунистичке партије, изборној кампањи за шпански парламент, односу према родном Кадису и Андалузији, Генерацији 
27, нарочито Антонију Маћаду, Федерику Гарсија Лорки и Висентеу Алејксандреу, итд.

б) у Биљешци о писиу, из које смо већ наводили његове критеријуме за избор Албертијевих песама, Јордан Јелић (1981: 123-130) се подробније бави тематским окосницама песникове ране стваралачке фазе. У уводном делу есеја - служећи се у у доброј мери закључцима и анализама из горепоменутог магистарског рада Далибора Солдатића - Јелић трага за идентификацијом Рафаела Албертија као песника мора, будући да та тема „у његовом пјесништву заузима централно мјесто“. Море у збирци Морнар на копну увек нужно подразумева и носталгију за детињством, безбрижношћу и успоменама из родног Кадиса, која је део песникове потраге за властитим бићем и људскошћу, односно отварања димензије „прошлог“ коју треба разумети као „једину могућу стварност садашњег“. За песме из збирке $O$ анђелима, настале нешто касније, у периоду песникових личних драма, „у процепу безнађа, ништавила, хаотичности“ Јелић (1981: 127) сматра да представљају квалитативни помак у контексту дотадашње Албертијеве поетике, тврдећи „с великом сигурношћу“ да у њима нема религиозности, односно да је „Албертијев свијет и поезија, свијет без бога“, у шта га je, како каже, у разговору уверио и са̂м песник, приликом гостовања на Струшким вечерима поезије у августу 1978. године.

Предговор књизи Изабране песме (1986) под насловом Песништво Рафаела Албертија Кринке Видаковић-Петров представља један од најсвеобухватнијих стручних осврта на Албертијеву поезију код нас. Видаковић-Петров на прегледан начин образлаже етапе кроз које се песник непрестано „мењао и обнављао“, од најраније поетике оваплоћене у прве три збирке, преко рехабилитације херметичног гонгоризма, излета у надреализам, „ургентне уметности“ Шпанског грађанског рата, која је непосредним потребама борбе и пропаганде подређивала естетске циљеве, социјално ангажоване поезије, поетских огледа посвећеним сликарству, итд (Видаковић-Петров 1986б: 8-24). Напис Кринке Видаковић-Петров има елементе прегледа књижевноисторијског карактера састављеног на основу богате литературе, а посебним ауторкиним доприносом могу се сматрати њени вредни аналитички осврти, тумачења и запажања, бројни како у предговору тако и у коментарима. У покушају да синтетички дефинише једну комплексну песничку биографију Видаковић-Петров (1986б: 26) за Рафаела Албертија каже да је био „херметични гонгориста, 
повремени надреалиста, недоследни авангардиста, елегичар, социјални песник, драмски писац, имитатор, пародичар, хумориста, пропагатор, сликар, марксиста, борац, емигрант - али пре свега и увек песник који животна искуства, своја и не само свог народа, историјска и савремена, као и 'сећања' на уметност и осећања њоме призвана, враћао, преносио, и претварао у поезију.“ Ауторка отуд закључује да Албертијева поезија, саздана на виђењу света као обреда, мита, бајке, трагедије, комедије и апсурда представља „променљиви исход непрестаног трагања за слободом у речи и на делу“.

Поред кратке похвале издању и преводу Кринке ВидаковићПетров, коју смо навели, Бошко Томашевић је највећи део приказа насловљеног „Рафаел Алберти или $O$ анђелима у њиховој нескривености“ (Летопис матище српске, 1987), посветио књижевно-естетској евалуацији Албертијевог песничког дела, с посебним критичко-поетичким освртом на збирку О анђелима. Један од најчувенијих [живих] шпанских песника, према Томашевићевој оцени, „упркос бројним до сада објављеним збиркама, аутор је тек једне уистину значајне песничке књиге, по којој ће, као Гонгора својим Самоћама или као Хорхе Гиљен својом Химном и Федерико Гарсија Лорка својим Циганским романсером, остати упамћен, и то тек међу читаоцима боље упућеним у поезију“ (Томашевић 1987: 962). Томашевић даље сматра да је првих неколико Албертијевих збирки написано као припрема за књигу $O$ анђелима, док осталих двадесетак представља песников напор да се „књига о анђелима унутар сопственог опуса превазиђе, или пак да се тек обнови врхунски песнички домет речене“ што се, према његовој оцени „на жалост није догодило“ (Томашевић 1987: 962). Томашевић објашњава (следећи делимично предговор Кринке Видаковић-Петров) да је Алберти пре и после те књиге прешао дуг песнички пут, пишући у стиху народне поезије, гонгоризма, ангажоване и експерименталне поезије (лирикографије), те изражавајући се у оквиру поменутих начина писања поезије кроз мноштво песничких облика: летриље, виљансика, сераниље, романсе, сонета, баладе, елегије, „сценске“ песме, а да „славу своје пете књиге никако не досегне“ јер збирка $O$ анђелима, „по својој уметничкој вредности, надмаша све оно што је Алберти пре и после ње створио“. Томашевићево (1987: 964) мишљење је да је O анђелима једина кохерентна збирка овог песника и коначно његова једина књига у којој се конзистентно исказује став „спрам 
вечних питања живота и смрти“. У тумачењу Албертијевих песама аутор се обилато користио књижевно-естетским судовима Владете Р. Кошутића и Сесила М. Бауре. Према Томашевићу (1987: 966) тема Анђела је тема изгубљеног раја, односно изгубљености логоса или „прецизније изгубљености језика бића. Отуд нам се на исти начин Албертијево песништво „указује као прикривени говор једног незнања која је преко свог излагања унутар логоса бива изведено на разину највише поезије.“ „На жалост“ - оцењује чини се ипак престрого Томашевић (1987: 966) - у Албертијевом случају „то се догодило у склопу казивања многобројних збирки тек само једанпут. Ово једанпут, пак, за многе песнике значи ниједанпут, и утолико је, и само утолико, Рафаел Алберти велики песник“.

Вредан прилог проучавању поетике Рафаела Албертија код нас представља рад Надреализам у Шпанији: пример Рафаела Албертија Далибор Солдатића (2007: 367-368) који проблематизује питање присуства надреалистичког тока у Шпанији, посебно се усредсређујући на пример Албертијеве збирке $O$ анђелима. Полазећи од мишљења историчара књижевности Жана Канавађа (Jean Canavaggio) да шпански песници никада у потпуности нису прихватили Бретонову технику аутоматског писања, Солдатић даје кратак увод у настанак и развој надреализма у шпанској уметности од Луја Арагона и Салвадора Далија, с посебним освртом на Буњуелов филм Андалузијски пас, настојећи да прво ближе одреди најкарактеристичније одлике тог покрета, а затим и да укаже на његове специфичне појавне облике у шпанској средини. Солдатић (2007: 369) у прилогу тврди да се надреализам, који се „дефинитивно јавља у Шпанији, мада недостају теоријски текстови и манифести“, никада суштински „није етаблирао као покрет“: тешко је било ког шпанског песника квалификовати искључиво као надреалисту - иако користе нека достигнућа нове технике и новог поимања стварности, шпански песници остају верни потрази за сопственим изразом. Најснажније се, према ауторовом мишљењу (Солдатић 2007: 371), сем код Албертија, елементи надреализма уочавају код песника Хуана Ларее (Juan Larrea), Висентеа Алејксандреа, Федерика Гарсија Лорке (Poeta en Nueva York) и Луиса Сернуде (Un río, un amor). Нова свест код млађе генерације писац нарочито оних који су тежили променама, ствара се под утицајем друштвене кризе, хипокризије владајуће класе, те политичке кризе у Шпанији тридесетих година XX века. Солдатић (2007: 371) истиче да је збирка О анђелима Рафаела Албертија једно од „најзначајнијих достигнућа 
шпанског надреализма“ упућујући, са становишта сагледавања поетичких елемената, пре свега на сам песнички имагинаријум, односно „галерију“ анђела из Албертијеве збирке. Свет Албертијевих анђела, према Солдатићу (2007: 374), „свет је духовних катастрофа“, а песник, упркос жељи да створи „кохерентан“ систем и пронађе одговоре на „егзистенцијална“ питања, наилази само на патњу и беспомоћност, немоћ која „проистиче из катастрофалног распарчавања личности. Песников его тоне у ништавило а небески и паклени анђели представљају метафизичке пројекције тог повређеног ега“ (Солдатић 2007: 375). Иако поједини анђели из ове Албертијеве збирке корене вуку из „традиције шпанске лирике“ што би „на неки начин указало на потпуно свестан и рационалан чин стварања, супротан надреалистичком методу“ - „одбацивање стварности и тежња ка чудесном“ условљавају „противречне знаке који разбијају разне видове стварног“ (Солдатић 2007: 376) и неминовно се везују за надреализам. У закључку Солдатић (2007: 376), потцртава: „Алберти није био надреалиста у свом целокупном опусу, али тренутак у ком ствара Sobre los ángeles, околности и крајњи плод су несумњиво надреалистички“.

У раду Дечији фолклор у авангардном и неопопуларистичком песништву Федерика Гарсија Лоркеи Рафаела Албертија анализирамо (2013: 223-235) присуство тзв. дечијег фолклора у поезији наведених аутора, како авангардног, тако и неопопуларистичког карактера, проучавали смо бавећи се начином на који су специфичне усмене фолклорне форме транспоноване у њихове поетике. Са језичкостилског аспекта анализиране су оне Албертијеве песме у којима се дечји фолклор препознаје као инспирација (Ratoncito Pérez, Dondiego sin don, La Pajara Pinta, Ja, je, ji, jo, ju). Значајно место у оквиру традиционалистичког тока под утицајем дечијег фолклора припада раној Албертијевој поезији, највише збирци Морнар на копну, за коју су карактеристични стил дечијих песмица и разбрајалица, игре речима које стоје ван логичких односа, као и хитанхафора стилско средство које Алберти користи најчешће међу савременим шпанским песницима. У раду се на примерима указује на формалностилске узоре из усмене шпанске дечје књижевности у неколиким неопопуларистичким и авангардним песмама поменуте двојице песника (Донић 2013: 237). 


\section{Закључна разматрања}

Полазећи од Јаусове теорије рецепције те теоријских специфичности рецепције књижевности у страној средини, може се закључити да су књижевни преводи Албертијевих песничких дела представљали нужан услов за успостављање културних и књижевних веза овог песника с југословенским читаоцима, као и за заснивање критичког односа према његовом делу у домаћем научном амбитусу. Трагове деловања посредника, „образованих читалаца" - почев од Хајима Алкалаја, Душка Вртунског, Јордана Јелића, Кринке Видаковић-Петров, Далибора Солдатића, Бошка Томашевића и др. - првих прималаца, интерпретатора и критичара шпанског песника у новој средини, посматрали смо као полазиште за проучавање односа између шпанског изворника, различитих превода објављених у југословенској средини, читалачке публике и самог процеса рецепције. На тим основама видокруг очекивања домаћег образованог читаоца спрам Албертијевог песничког дела покушали смо да делом реконструишемо на основу доступних извора, језичко-стилске анализе превода, као и анализе перспективе компетентних посредника који су га с тим делом упознали.

Премда спорадични преводи у књижевној периодици које смо навели сведоче о интересовању за Албертијево песничко дело у нашој средини од тридесетих година XX века, тек су преводи у форми књиге $(1973,1981,1986)$ обезбедили услове за живљу рецепцију у широј југословенској читалачкој публици српскохрватског језика. Као ангажован књижевник, антифашиста и левичар, Алберти је уживао неподељенесимпатије југословенскихчиталаца, критичара и песника на идеолошкој основи, што је рецепцију умногоме олакшало те оснажило песникове личне и културне везе са СФР Југославијом. Две збирке у преводу Јордана Јелића, једног од најеминентнијих југословенских преводилаца и латиноамериканиста друге половине XX века, омогућиле су иницијални пробој Албертијеве поезије у нашу средину, постављајући темеље стилски и метрички адекватној рецепцији његовог обимног песничког дела, нарочито збирки Драгана, Морнар на копну и О анђелима. Међутим као много обухватнији и пропраћенији, подухват Кринке Видаковић-Петров представља најважнији књижевни догађај у рецепцији тог песника у југословенској културној средини. Обимна и репрезентативна збирка Изабране песме доноси успео превод, а њен допринос исправнијој и широј рецепцији поезије Рафаела Албертија на српском 
говорном подручју тек треба темељније дијахронијски проучити. Ауторка је Албертијевом делу пришла стручно, као хиспанисткиња, компаратисткиња, компетентна читатељка и напосе талентована књижевна преводитељка. Антологија Изабране песме имала је добар пријем и одјек у нашој компетентној читалачкој публици будући да је исте године превод Кринке Видаковић-Петров вреднован престижном наградом „Милош Ђурић“ Удружења књижевних преводилаца Србије.

Највише интересовања домаће критике изазвале су Албертијеве збирке Морнар на копну и $O$ анђелима - као врхунско дело европског надреализма, којима су вредне текстове посветили Далибор Солдатић и Бошко Томашевић. За критичку рецепцију песничког дела Рафаела Албертија на српском говорном подручју, која према нашем сазнању обухвата, сем пропратних текстова у изборима песама о којима смо писали, тек неколико поменутих критичких приказа, осврта и поетичких описа, ипак се мора рећи да је релативно скромна, нарочито у односу на важност овог песника за шпанско песништво, али и шире, у оквирима историје светске књижевности.

\section{ИЗВОРИ}

\section{Преводи: књиге}

Алберти, Рафаел. Драгана, избор, превод и поговор Јордан Јелић. Крушевац: Багдала, 1973.

Alberti, Rafael. Mornar na kopnu i druge pjesme, izbor i prevod Jordan Jelić. Titograd: Pobjeda, 1981.

Alberti, Rafael. Izabrane pesme, izbor, prevod, predgovor, komentari i hronologija Krinka Vidaković Petrov. Beograd: BIGZ, 1986.

\section{Преводи: књижевна периодика}

Alberti, Rafael. „Poziv harfi“, preveo sa španskog Hajim Alkalaj. Pregled, 146 (1936): 69.

Алберти, Рафаел. „Зора која именује“, са шпанског превео Душко Вртунски. Летопис Матище српске, 139, 392, 1 (1963): 58.

Alberti, Rafael. „Mornar na kopnu“, sa španjolskog preveo Jordan Jelić. Časopis za književnost i kulturu - Život, God. XXIV, knj. XLVIII, br. 7-8 (1975): 34-49. 
Алберти, Рафаел „Madrigal o Snjeguljici“, „Sirenica djevica“, „Jednom kapetanu“, „Federiku Garsiji Lorki“, „Rozi Alberti, koja je sjetna svirala na harfi“, „Poletjeti!“, „Srna moja“, „Zemljotres“, „Od dva do tri“, „Elegija“, „Dragana“, „Gospođici X, sahranjenoj u zapadnom vjetru“, „Dobri anđeo“, „Telegram“, „Galop“, „U petoj sam regimenti!“, prevod sa španskog i beleške o pesniku Jordan Jelić. Polja, God. 24, br. 230 (1978): 20-21.

Алберти, Рафаел. „Сликарству: (фрагменти)“, превео Јордан Јелић. Летопис Матице српске, 155, 423, 1 (1979): 51-56.

Алберти, Рафаел. „Десет песама“ [Пешаци чувајте се Рима, Забрањено мокрити, Кампо де Фиори; Песнички живот; Базилика С. Петра; Господе, буди милосрдан; Улазим у иркве твоје; Артритис II; Мост дојки; *** [Борба са мачкама у Риму...], италијанског превела Кринка Видаковић Петров. Летопис Матище српске, 156, 425, 2 (1980): 261-266.

Alberti, Rafael. „Izgubljeni raj“, „Smrt i sud“, „Poziv harfi“, „Mrtvi anđeli“, „Ružni anđeli“, „Preživeli anđeli“, preveo Branislav Prelević. Савременик, God. 26, knj. 51, sv. 6 (1980): 465-470.

Алберти, Рафаел. „Песме“ [Интернационалним бригадама, Елегија за песника који није имао своју смрт], превео Бранислав Прелевић. Повеља, Год. 16, бр. 1 (1986): 30-31.

Алберти, Рафаел. „Халејева комета“, „Луис Буњуел у Венецији“, „Нешто о Јасмину, души која лута из Пунте дел Есте“, са шпанског Душка Радивојевић. Летопис Матище српске, Год. 162, књ. 437, св. 5-6 (1986): 745-749, 931-938.

Алберти, Рафаел. „О анђелима“, превео са шпанског Јордан Јелић. Летопис Матице српске, 175, 463, 1-2 (1999): 73-78.

Алберти, Рафаел. „Лакоми анђео“, са шпанског превео Никола Милићевић. Овдје, Год. 32, бр. 388/390 (2001): 31.

Алберти, Рафаел. „Балада о бициклу са крилима“, „Отворена карта“, превод Лепота Кузмановић. Багдала, Год. 56, бр. 502 (2014): 76-77, 89-90.

\section{БИБИЛИОГРАФИЈА}

Алберти 1972: Rafael Alberti. Marinero en tierra, La amante, El alba del alhelí. Edición, introducción y notas de Robert Marrast. Madrid: Castalia.

Алберти 1981: Rafael Alberti. Mornar na kopnu i druge pjesme, izbor i prevod Jordan Jelić. Titograd: Pobjeda. 
Алберти 1986: Rafael Alberti. Izabrane pesme, izbor, prevod, predgovor, komentari i hronologija Krinka Vidaković Petrov. Beograd: BIGZ.

Буњак 1998: Петар Буњак. „О питању историје рецепције стране књижевности“. Књижевна историја, Год. 30, бр. 104, 5-26.

Видаковић-Петров 1986a: Krinka Vidaković-Petrov. „Komentari prevodioca". Rafael Alberti,Izabrane pesme, izbor, prevod, predgovor, komentari i hronologija Krinka Vidaković Petrov. Beograd: BIGZ, 235-303.

Видаковић-Петров 1986б: Krinka Vidaković-Petrov. „Pesništvo Rafaela Albertija“. Rafael Alberti, Izabrane pesme, izbor, prevod, predgovor, komentari i hronologija Krinka Vidaković Petrov. Beograd: BIGZ, $7-26$.

Вучковић 2008: Радован Вучковић. Писац, дело, читалац (о креативном писању, читању и интерпретацији). Београд : Службени гласник.

Гардић 1954: Miodrag Gardić. „Rafael Alberti“. Iz savremene španske lirike: Sto odabranih pesama, odabrao i preveo Miodrag Lj. Gardić. Beograd: Rad, 75.

Донић 2013: Жељко Донић. „Дечији фолклор у неопопуларистичкој и авангардној поезији Федерика Гарсије Лорке и Рафаела Албертија. Зоран Пауновић \& Биљана Дојчиновић (уредници), Филолошка истраживања данас, Том IV: Парадигме, утицаји, рецепција, Београд: Филолошки факултет, 223-235.

Јанићијевић 1977: Jovan Janićijević. „Prevodna i nacionalna književnost“. Kultura, 186-192.

Jayc 1978: Hans Robert Jaus. Estetika recepcije, prevela Drinka Gojković, Predgovor Zoran Konstantinović. Beograd: Nolit.

Јелић 1973: Jordan Jelić. „O pesniku“. Rafael Alberti, Dragana, izbor, prevod i pogovor Jordan Jelić. Kruševac: Bagdala, 33-37.

Јелић 1975: Jordan Jelić. „Bilješka o piscu“. Časopis za književnost i kulturu „Život", God. XXIV, knj. XLVIII, br. 7-8: 49-50.

Јелић 1981: Jordan Jelić. „Bilješka o piscu“. Rafael Alberti, Mornar na kopnu i druge pjesme, izbor i prevod Jordan Jelić. Titograd: Pobjeda, 123-130.

Кошутић 1963: Владета Р. Кошутић. „Предговор“. Шпанска лирика, избор, препев и предговор Владета Р. Кошутића. Београд: Просвета, 5-65.

Куленовић 1988: Tvrtko Kulenović. Moderna tumačenja književnosti. Sarajevo: Svjetlost. 
Лалић 1981: Borislav Lalić. „Odnesite me na more“. Rafael Alberti, Mornar na kopnu i druge pjesme, izbor i prevod Jordan Jelić. Titograd: Pobjeda, 109-122.

Милићевић 1972: Nikola Milićević. „Predgovor“. Zlatna knjiga španjolske poezije: od XII do XX stoljeća, sastavio i preveo Nikola Milićević. Zagreb: Matica hrvatska, 5-19.

Солдатић 1969: Dalibor Soldatić. La nostalgia en la Obra Poética de Rafael Alberti. (Universidad Nacional Autónoma de México). [Необјављена магистарска теза, на шп.].

Солдатић 2007: Далибор Солдатић. „Надреализам у Шпанији: пример Рафаела Албертија“. Јелена Новаковић (ур.), Надреализам у свом и нашем времену. Београд: Филолошки факултет, 367378.

Солдатић 2001: Далибор Солдатић. „Морнар на копну: Рафаел Алберти (1902-1999)“. Овдје, Год. 32, бр. 388/390: 28-30.

Томашевић 1987: Бошко Томашевић. „Рафаел Алберти или $O$ анђелима у њиховој нескривености“ (Приказ књиге: Рафаел Алберти. Изабране песме. Избор, превод, предговор, коментари и хронологија Кринка Видаковић Петров, Београд, 1986). Летопис Матище српске, Год. 163, књ. 439, св. 6: 962-967. 


\title{
MEDIATORS AND RECEPTION: \\ TRANSLATION AND CRITIQUE OF RAFAEL ALBERTI'S POETIC WORK IN THE YUGOSLAV CULTURAL ENVIROMENT
}

\begin{abstract}
Summary
The paper examines the various elements of the reception of the poetic work of the Spanish poet Rafael Alberti in the Yugoslav cultural environment, with particular reference to the role and importance of the mediators (translators, interpreters and critics) between the poet and the readership in Serbo-Croatian. Starting from Hans Robert Jauss's reception theory and the theoretical peculiarities of the reception of literature in a foreign environment, translation is observed as a necessary condition for establishing cultural and literary connections of Alberti's poetry with Yugoslav readers, as well as for founding a critique towards his work in the domestic scientific milieu. Traces of the work of the mediator, as an educated reader, who in most cases is the first recipient of the work, the first interpreter, and often his first evaluator in the new environment, are seen as valuable sources and starting points for studying the relationship between the original Alberti's work, translation in the Yugoslav environment, new reading audiences and receptions. On this basis, the Horizon of expectations of the educated Serbo-Croatian speaking Yugoslav reader in relation to Alberti's poetry can be partially reconstructed on the basis of an analysis of the perspectives of the mediators who introduced it into a new environment.
\end{abstract}

Keywords: reception of literature in a foreign environment, literary translation, poetry of Rafael Alberti. 